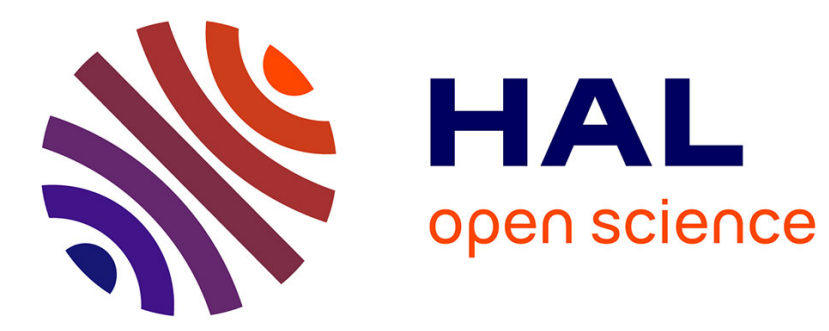

\title{
Elasticity of Si-C-O and C fibres at high temperature
}

Ml Bouchetou, Thierry Cutard, M Huger, C Gault

\section{To cite this version:}

Ml Bouchetou, Thierry Cutard, M Huger, C Gault. Elasticity of Si-C-O and C fibres at high temperature. Scripta Materialia, 1997, 37 (7), pp.1005-1010. 10.1016/S1359-6462(97)00214-5 . hal-01714948

\section{HAL Id: hal-01714948 \\ https://hal.science/hal-01714948}

Submitted on 6 Nov 2019

HAL is a multi-disciplinary open access archive for the deposit and dissemination of scientific research documents, whether they are published or not. The documents may come from teaching and research institutions in France or abroad, or from public or private research centers.
L'archive ouverte pluridisciplinaire HAL, est destinée au dépôt et à la diffusion de documents scientifiques de niveau recherche, publiés ou non, émanant des établissements d'enseignement et de recherche français ou étrangers, des laboratoires publics ou privés. 


\title{
ELASTICITY OF Si-C-O AND C FIBRES AT HIGH TEMPERATURE
}

\author{
M.L. Bouchetou, T. Cutard*, M. Huger and C. Gault \\ Laboratoire Matériaux Céramiques et Traitements de Surfaces \\ ENSCI, 87065 Limoges, France \\ "Ecole des Mines d'Albi Carmaux, 81013 Albi, France
}

\begin{abstract}
Introduction
The knowledge of the evolution versus temperature of the elastic moduli of fibres used for making ceramic matrix composites (CMCs) is necessary to understand their behavior in service conditions, i.e. at high temperature. Some results have been obtained from tensile tests performed on refractory fibres (i.e. carbon or ceramics), using specific equipments (1-4). However, the determination of Young's modulus from the slope at the origin of the stress-strain curve is difficult (in particular at high temperature and under controlled atmosphere) due to the thinness of the samples. Another way to determine elastic constants of materials is to use non destructive ultrasonic pulse-echo techniques. This has been made in composites with matrix of known elastic properties (5-7) where the authors have calculated the elastic constants of the fibres from experimental results. Unfortunately this method has not been applied at elevated temperatures.

This paper reports on direct measurements of uniaxial Young's modulus in refractory fibres using a particular ultrasonic pulse-echo technique in the $20^{\circ} \mathrm{C}-1300^{\circ} \mathrm{C}$ temperature range. Amongst the most widely used fibres for CMCs industrial fabrication, we have tested two types: Nicalon NLM 202 (Si-C-O) from. Nippon Carbon and T300 (C) from Toray.
\end{abstract}

\section{Experimental Procedure}

The technique, which has been described elsewhere (8), consists in measuring the velocity of ultrasonic longitudinal waves in slender specimens via a refractory waveguide ("long bar" mode). The conditions for the propagation of this mode are $D<\lambda$ and $L>\lambda$, where $D$ is the sample diameter, $L$ is the sample length and $\lambda$ is the wavelength. The technique works at a low frequency $(300 \mathrm{kHz})$ which leads to a wavelength of some centimeters in solids. Then it is well suited for measurements into thin samples like fibres.

Samples $80 \mathrm{~mm}$ long have been cut from as-fabricated yarns made of 500 filaments of $10-15 \mu \mathrm{m}$ diameter for NLM202 and of 1000 filaments of 6-8 $\mu \mathrm{m}$ diameter for T300. The sample diameter was then inferior to $2 \mathrm{~mm}$. It was glued to the end of an alumina waveguide by a refractory cement. In 
order to maintain the straightness of the fibres, they were placed into an alumina tube with the waveguide as shown in Figure 1. The system was vertically fitted in a gastight tube into a furnace; it was able to work up to $1700^{\circ} \mathrm{C}$ in controlled atmosphere (free air, primary vacuum or argon).

Before starting the experiments, a first heating treatment of $30 \mathrm{~min}$ at $400^{\circ} \mathrm{C}$ in air for NLM202 and at $600^{\circ} \mathrm{C}$ in $\mathrm{Ar}$ for $\mathrm{T} 300$ has been made in order to remove the sizing on the fibres.

When complete desizing was achieved, it was assumed that the ultrasonic pulse propagated in the long bar mode along the isolated identical filaments with the velocity $V$ related to the uniaxial Young's modulus $E$ of one filament and to density $\rho$ by :

$$
E=\rho V^{2}
$$

$\mathrm{V}$ was evaluated from the measurement of the time $\tau$ between successive echoes in the sample as reported in ref.(8):

$$
\mathrm{V}=2 \mathrm{~L} / \tau
$$

Results obtained during temperature runs at a constant rate of $5^{\circ} \mathrm{C} / \mathrm{min}$ were plotted under the form $\left(E-E_{0}\right) / E_{0}=f(T)$, where $E_{0}$ is the value corresponding to $T=20^{\circ} \mathrm{C}$ after removing the sizing.

\section{$\underline{\text { Results and Discussion }}$}

The uniaxial Young's moduli $\mathrm{E}_{0}$ along the axis of the fibres measured at $20^{\circ} \mathrm{C}$ after removing the sizing are given in Table 1 .

They are in good agreement with results reported in the literature for similar fibres. Thermal expansion coefficients $\alpha$ along the fibre axis and density $\rho$ which are used for the calculation of $E$ by equations (1) and (2) are also listed in Table 1. For T300 there is some discrepancy between different authors about thermal expansion, in particular because of the anisotropic and nonlinear behavior versus temperature of the thermal expansion of carbon. Nevertheless for both fibres, $\alpha$ is lower than $510^{-6}$ and

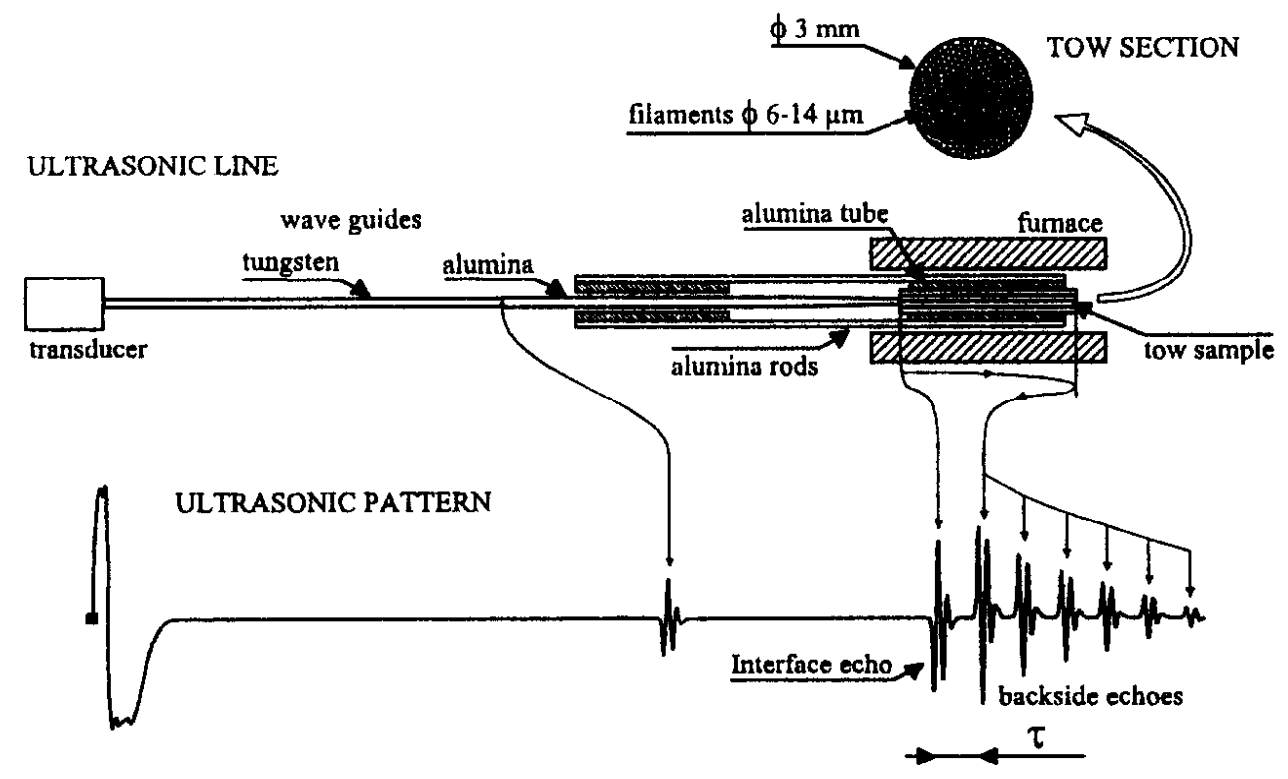

Figure 1. Details of sample/waveguide assembly for uitrasonic measurements at high temperature in fibres, and associated ultrasonic pattern. 
TABLE 1

Young's Modulus at $20^{\circ} \mathrm{C}\left(\mathrm{E}_{0}\right)$, Thermal ExpansionCoefficient $(\alpha)$, and Density $(\rho)$, for the Si-C-O (NLM202) and C (T300) Fibres

\begin{tabular}{cccc}
\hline FIBRE & $\mathrm{E}_{0}(\mathrm{GPa})$ & $\alpha .10^{\mathrm{f}}\left(\mathrm{K}^{-1}\right)$ & $\rho\left(\mathrm{kg} \cdot \mathrm{m}^{-3}\right)$ \\
\hline NLM 202 & $215+1-2\left(^{*}\right)$ & $\begin{array}{c}3.4(\mathrm{ref} .12) \\
\left(20^{\circ} \mathrm{C}-1000^{\circ} \mathrm{C}\right)\end{array}$ & $2550($ ref.13) \\
\hline T300 & $221+1-2\left(^{*}\right)$ & $\begin{array}{l}<4 \text { (ref.4,12) } \\
\text { (temp. dep.) }\end{array}$ & 1800 (ref.6) \\
\hline
\end{tabular}

the length correction in equations (1) and (2) remains negligible compared to the experimental error (1\%).

\section{Evolutions of Young's Modulus Versus Temperature for NLM202}

The Si-C-O Nicalon NLM202 fibre is composed, in the as-processed state, of $\beta$-SiC nanocrystals (55wt.\%) mixed with a $\mathrm{SiO}_{1.15} \mathrm{C}_{0.85}$ intergranular phase (40wt.\%) and basic structural units (BSU) of free carbon (5wt.\%) (10). This structure is stable up to $1000^{\circ} \mathrm{C}$ in non oxidizing atmosphere. At higher temperature, the organization of BSU and the decomposition of the intergranular phase induce irreversible modifications. Therefore $1000-1100^{\circ} \mathrm{C}$ is the highest temperature range for long time applications of NLM202 based CMCs.

Curve (1) in Figure 2 reports the variations of $\mathrm{E}$ measured during a temperature run between $20^{\circ} \mathrm{C}$ and $1050^{\circ} \mathrm{C}$ in primary vacuum $\left(510^{-2} \mathrm{hPa}\right)$, which can be considered as non oxidizing conditions for this fibre (14). A regular and reversible decrease versus temperature is observed. A second run leads to a perfectly superimposed curve within the experimental error. This is characteristic of a stable structure of the material within the tested temperature range (15).

Compared to sintered SiC, Si-C-O fibres exhibit strong differences in elastic behavior :

- at room temperature $\mathrm{E}_{0}=215 \mathrm{GPa}$ for NLM202 instead of $400 \mathrm{GPa}$ for sintered $\mathrm{SiC}$;

- E linearly decreases with increasing temperature up to $1200^{\circ} \mathrm{C}$ with a slope $1 / \mathrm{T} . \mathrm{dE} / \mathrm{E}$ of - 7.6 $10^{-5} \mathrm{~K}^{-1}$ for sintered $\mathrm{SiC}(16)$. In the case of NLM202, E remains constant up to $500^{\circ} \mathrm{C}$ and then decreases with an increasing rate which becomes comparable to that of $\mathrm{SiC}$ at $1000^{\circ} \mathrm{C}$, $1 / \mathrm{T} \cdot \mathrm{dE} / \mathrm{E}=-6 \cdot 10^{-5} \mathrm{~K}^{-1}$.

Curve (2) in Figure 2 shows the result of the same test performed in air at atmospheric pressure, without taking into account mass variations. In air, the curve drops for $\mathrm{T}>600^{\circ} \mathrm{C}$ and the apparent Young's modulus at $1000^{\circ} \mathrm{C}$ is $3 \%$ lower than $\mathrm{E}$ in non oxidizing atmosphere. Furthermore the curve is not reversible and after cooling to room temperature, it remains lower than $E_{0}$. This effect can be attributed to the formation of a silica layer around the fibres above $600^{\circ} \mathrm{C} \mathrm{(17):} \mathrm{each} \mathrm{filament} \mathrm{is} \mathrm{pro-}$ gressively transformed into a $\mathrm{Si}-\mathrm{C}-\mathrm{O} / \mathrm{SiO}_{2}$ microcomposite with a Young's modulus lower than $\mathrm{E}$ for $\mathrm{Si}-\mathrm{C}-\mathrm{O}(\mathrm{E} \approx 70 \mathrm{GPa}$ for silica). Moreover, this oxidation is accompanied simultaneously by a volume expansion of the fibre and a mass increase, as it was previously shown by SEM observations and TGA measurements on the same fibre (17). Therefore density variations occur when the samples are oxi- 


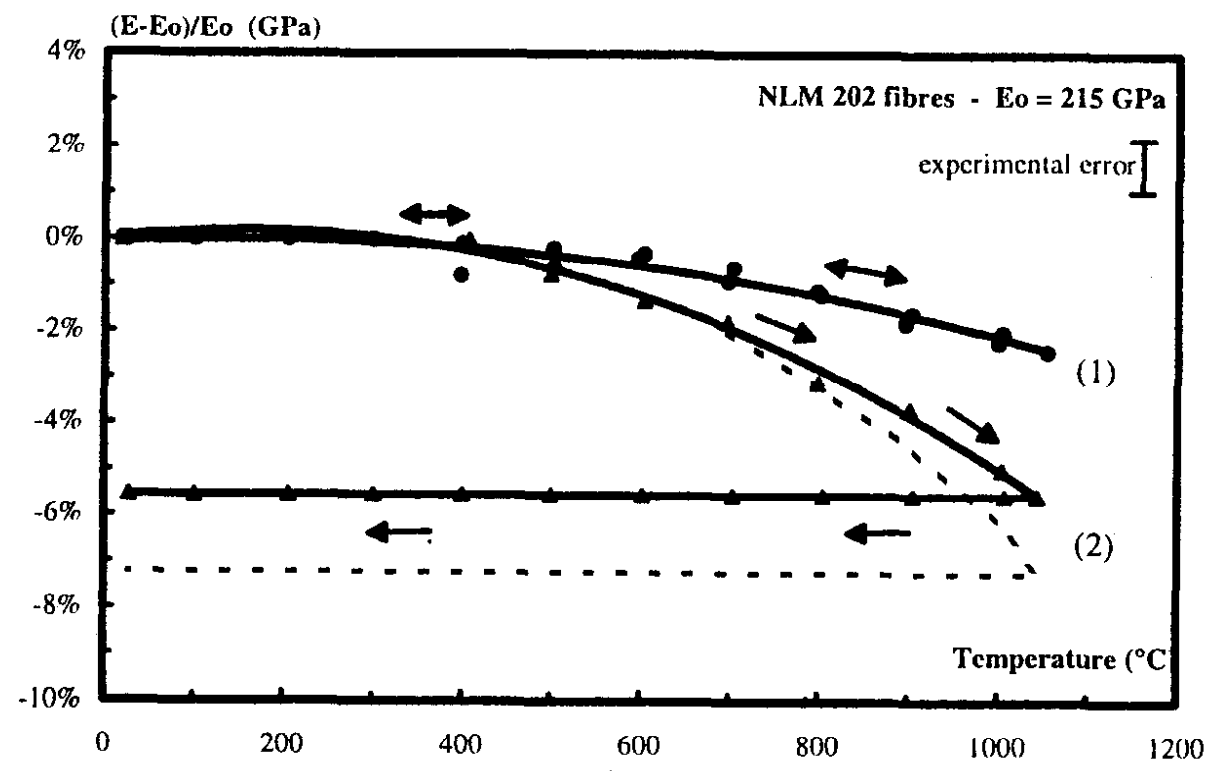

Figure 2. Relative variations of Young's modulus in NLM 202 fibre during heating/cooling cycles up to $1050^{\circ} \mathrm{C}$ at $5^{\circ} \mathrm{C} / \mathrm{min}$ : (1) primary vacuum; (2) air, atmospheric pressure without mass correction; the dotted curve corresponds to the lowest bound of curve (2) corrected for mass variations.

dized at high temperature and corrections have to be made in equ. (1) for the true evaluation of $E(T)$. From results of ref.(17) the variation of density induced by oxidation can be calculated as follows:

$$
\Delta \rho / \rho_{\mathrm{o}}=-2.410^{-4} \mathrm{e}
$$

where $\mathrm{e}$ is the thickness of the silica layer expressed in $\mathrm{nm}$.

For aging $1 \mathrm{~h}$ at $1000^{\circ} \mathrm{C}$ in air, e was found to be approximately $70 \mathrm{~nm}$. Therefore the variation of $\mathrm{E}$ coming from the decrease of $\rho$ in equ. (1) remains lower than $-1.7 \%$ at $1000^{\circ} \mathrm{C}$. The dotted curve in Figure 2 gives the lowest bound for the variation of Young's modulus in air.

\section{Evolutions of Longitudinal Young's Modulus Versus Temperature for T300}

Figure 3 shows the variations of $\mathrm{E}$ during heating at a rate of $5^{\circ} \mathrm{C} / \mathrm{min}$. up to $1270^{\circ} \mathrm{C}$ under argon. After a dwell of $0.5 \mathrm{~h}$ at $1270^{\circ} \mathrm{C}$, the sample was cooled down to RT and a new coupling to the waveguide was made in order to determine the new value at $20^{\circ} \mathrm{C}$. Two domains are observed on the $\left(E-E_{0}\right) / E_{o}=f(T)$ curve:

-for $\mathrm{T}<1100^{\circ} \mathrm{C}, \mathrm{E}$ remains approximately constant;

-for $\mathrm{T}>1100^{\circ} \mathrm{C}$, an increase of $\mathrm{E}$ is observed at a rate which increases with temperature. During the dwell, E increases with time.

This effect is irreversible even after cooling: the new value at $20^{\circ} \mathrm{C}$ is $8 \%$ higher than $\mathrm{E}_{0}$ which exactly corresponds to the increase between $1100^{\circ} \mathrm{C}$ and the end of the dwell at $1270^{\circ} \mathrm{C}$. It suggests that a structural transformation which induces an increase in elastic modulus along the axis occurred in the fibre above $1100^{\circ} \mathrm{C}$.

The elastic properties of carbon-based crystallized materials cover a wide range because of the existence of numerous carbon types which are characterized by the order degree of the graphitic planes. The structure of ex-PAN fibres is generally described as crystals with a ribbon-like arrange- 


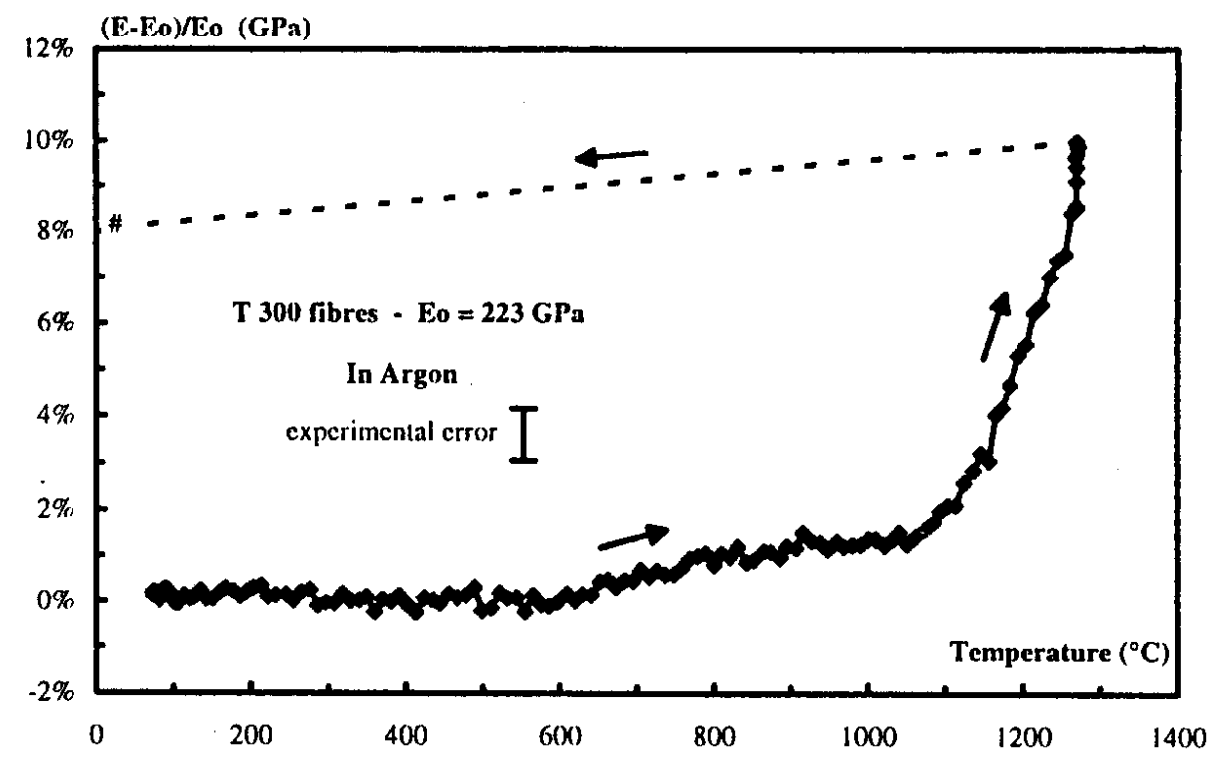

Figure 3. Relative variations of longitudinal Young's modulus in T300 fibre during heating under Ar up to $1270^{\circ} \mathrm{C}$ at $5^{\circ} \mathrm{C} / \mathrm{min}$. (\#) value measured at $20^{\circ} \mathrm{C}$ after $2 \mathrm{~h}$ at $1270^{\circ} \mathrm{C}$.

ment of such planes, which are more or less oriented with respect to the fibre axis and separeted by nanopores. This structure strongly depends on the heat treatment used for processing: pyrolysis at $1000^{\circ} \mathrm{C}$ leads to porous unorganized structures and subsequent heat treatments at higher temperatures improve graphitization $(18,19)$. The higher the temperature, the better is the ordering of graphitic planes, the higher the elastic modulus and the lower the ultimate strenght of the fibre (20). T300 are "high strength fibres" treated at a temperature inferior to $1500^{\circ} \mathrm{C}$ which leads to incomplete graphitization. Therefore the irreversible increase of longitudinal Young's modulus above $1100^{\circ} \mathrm{C}$ is a consequence of the improvement of graphitization.

Furthermore, it is expected that graphitization should be accompanied by densification due to the decrease of porosity. Consequently, the measured Young's modulus should be corrected at $\mathrm{T}>1100^{\circ} \mathrm{C}$. The values of $E$ and $\rho$ reported in literature range from $230 \mathrm{GPa}, 1750 \mathrm{~kg} . \mathrm{m}^{-3}$ for low graphitic fibres, up to $700 \mathrm{GPa}, 2050 \mathrm{~kg} \cdot \mathrm{m}^{-3}$ for high graphitic fibres, respectively, and the variation of $\mathrm{E}$ versus $\rho$ is approximately linear (19). Data interpolation shows that graphitization which induces an increase of $10 \%$ in $\mathrm{E}$, involves an increase of $\rho$ of less than $1 \%$. This correction is negligible because it is of the same order of magnitude than the experimental error.

\section{Conclusion}

Ultrasonic measurements of Young's modulus allow us to know the temperature range of structural stability of refiractory fibres which are used for CMCs fabrication. In particular, it has been found that the oxidation of Nicalon NLM 202 in air above $600^{\circ} \mathrm{C}$ induces a decrease of elastic properties, and that heating $\mathrm{T} 300$ in $\mathrm{Ar}$ above $1100^{\circ} \mathrm{C}$ improves the longitudinal Young's modulus because of graphitization. Such a technique can be used to investigate the effect of numerous structural changes at high temperature on the elastic behavior of fibres. It is obviously of practical interest for life time prediction of CMCs parts in service. 


\section{$\underline{\text { References }}$}

1. A.R. Bunsell, J.W.S. Hearle, R.D. Hunter, J. Phys. E Sci. Instr., 4, 868, (1971).

2. R.E. Tressler, J.A. Di Carlo, in High-Temperature Ceramic-Matrix Composites, R. Naslain, J. Lamon \& D. Doumeingts eds., Woodhead publ. Itd., 33 (1993).

3. A.R. Bunsell, M.H. Berger, N. Hochet, in High-Temperature Ceramic-Matrix Composites II, A. Evans \& R. Naslain eds., Ceramic Trans. vol.58, Amer. Ceram. Soc. publ., 85 (1995).

4. S. Marion, Thesis, Paris XIII Univ., France (1993).

5. R.E. Smith, J. Appl. Phys., 43, 6, 2555 (1972).

6. T. Ishakawa, K. Koyama, S. Kobayashi, Jour. of Comp. Mater., 11, 332 (1977).

7. H.M. Ledbetter, S.K. Datta, T. Kyono, J. Appl. Phys., 65, 9, 3411 (1989).

8. T. Cutard, D. Fargeot, C. Gault, M. Huger, J. Appl. Phys., 75, 4, 1909 (1994).

9. M. Takeda, J. Sakamoto, A. Saeki, Y. Imai, H. Ichikawa, Ceram. Engn. \& Sci. Proc. 16, 4, 37 (1995).

10. P. Le Coustumer, M. Monthioux, A. Oberlin, Jour. Eur. Ceram. Soc., 11, 95 (1995).

11. A.S. Fareed, P. Fang, M.J. Koczack, F.M. Ko, Ceram. Bull., 66, 2, 353 (1987).

12. J.F. Villeneuve, R. Naslain, J. Sevely, R. Fourmeaux, Compos. Sci. \& Technol., 49, 89 (1993).

13. C. Aubin, C. Lesniewsky, Jour. de Microscopie et Spectro. Electr., 12, 471 (1987).

14. M. Huger, Thesis, Limoges University, France (1992).

15. C. Gault, in Mat. Res. Soc. Proc., eds. Mater. Res. Soc., vol. 142, 263 (1989).

16. R.L. Mehan, Jour. Mater. Sci., 13, 358 (1978).

17. M. Huger, S. Souchard, C. Gault, Jour. Mater. Sci. Let., 12, 414 (1993).

18. M. Guigon, A. Oberlin, G. Desarmot, Fibre Science and Technol., 20, 55 \& 177 (1984).

19. M.L. Bouchetou, Thesis, Limoges University, France (1996).

20. C.N. Tyson, J. Phys. D, 8, 749 (1975). 